\title{
PROBLEMATIKA PELAKSANAAN ABORSI BAGI KORBAN PERKOSAAN DALAM UNDANG-UNDANG NOMOR 36 TAHUN 2009 TENTANG KESEHATAN*
}

\author{
Yenny Fitri.Z \\ STIH Putri Maharaja Payakumbuh, \\ Jln. Prof. Dr.Hamka No 108 Kota Payakumbuh \\ e-mail: yennyfitri@rocketmail.com
}

\begin{abstract}
Rape is a frightening crime for women because the impact of rape is not only felt when the crime is committed, but also affects the future. One of them is an unwanted pregnancy. For rape victims, the choice of continuing an unwanted pregnancy or having an abortion is an equally difficult choice. Basically, abortion is clearly a prohibited act, both legally, morally, ethically, decently, and religiously. Although prohibited, abortion cases in Indonesia actually show an increase every year. In response to the problem of abortion for victims of rape, the government has given birth to Law Number 36 of 2009 concerning Health. However, since the legal umbrella was born, it has been minimal and in fact there have been almost no rape victims who have used this safe abortion practice as a way to abort their unwanted abortion. This happens because of problems in the field of practice, it is not as easy as the description of the theory set forth in the legislation. While almost every day rape victims continue to fall in all parts of Indonesia. To answer this problem, the author conducts research using normative juridical methods. Thus it is expected to be able to find problems or problems in the implementation of abortion for victims of rape based on Law Number 36 of 2009 concerning Health. The research shows that there are three problems in Law Number 36 Year 2009 regarding Health which makes it difficult for rape victims to obtain safe and legal abortion services. These problems include the maximum obstetrical age of 40 days for abortion for rape victims to be considered too short, the Ministry of Health has never prepared training requirements for medical personnel and counseling training for abortion for rape victims, then health services that meet the conditions set by the Minister is still very limited and cannot be easily accessed in any part of Indonesia. Therefore, the problematic implementation of legal and safe abortion for rape victims found in the Health Act must be immediately corrected, so that rape victims do not return to become victims due to the implementation of unsafe illegal abortion practices.
\end{abstract}

Keywords: Problems; Abortion; Rape Victim.

\begin{abstract}
Abstrak
Perkosaan adalah salah satu kejahatan yang menakutkan bagi perempuan karena dampak dari perkosaan tidak hanya dirasakan ketika kejahatan tersebut dilakukan, tetapi juga berimbas pada masa yang akan datang. Salah satunya kehamilan yang tidak diinginkan. Bagi korban perkosaan, pilihan untuk melanjutkan kehamilan yang tidak diharapkan atau melakukan tindakan aborsi adalah pilihan yang sama sulitnya. Pada dasarnya, aborsi jelas merupakan tindakan yang dilarang, baik secara hukum, moral, etika, kesusilaan, dan agama. Meski dilarang, kasus aborsi di Indonesia justru menunjukkan peningkatan setiap tahunnya. Sebagai jawaban atas permasalahan aborsi bagi korban perkosaan ini, pemerintah sudah melahirkan Undang-Undang Nomor 36 Tahun 2009 tentang Kesehatan. Namun, sejak payung hukum tersebut dilahirkan, sangat minim dan bahkan hampir tidak ada korban perkosaan yang menggunakan praktek aborsi aman ini sebagai jalan untuk menggugurkan kandungan yang tidak diinginkannya. Hal ini terjadi karena permasalahan di lapangan praktek, tidak semudah uraian teori yang dituangkan di dalam peraturan
\end{abstract}

\footnotetext{
* Naskah diterima: 23 Agustus 2019, direvisi: 1 September 2019, disetujui untuk terbit: 30 September 2019

Doi: $10.3376 /$ jch.v5i1.205
} 
Yenny Fitri.Z : Problematika Pelaksanaan Aborsi Bagi Korban Perkosaan...

perundang-undangan. Sementara hampir setiap hari korban perkosaan terus berjatuhan di semua wilayah Indonesia. Untuk menjawab persoalan tersebut, Penulis melakukan penelitian dengan metode yuridis normatif. Dengan demikian diharapkan dapat menemukan persoalan atau problematika pelaksanaan aborsi bagi korban perkosaan berdasarkan Undang-Undang Nomor 36 Tahun 2009 tentang Kesehatan. Dari penelitian diperoleh hasil bahwa ada tiga persoalan dalam Undang-Undang Nomor 36 Tahun 2009 tentang Kesehatan yang menyulitkan korban perkosaan untuk mendapatkan layanan aborsi yang aman dan legal. Persoalan tersebut meliputi usia kandungan yang ditetapkan maksimal 40 hari untuk dapat dilakukannya aborsi bagi korban perkosaan dinilai terlalu singkat, Kementerian Kesehatan belum pernah mempersiapkan persyaratan pelatihan terhadap tenaga medis dan pelatihan konseling untuk aborsi bagi korban perkosaan, kemudian layanan kesehatan yang memenuhi syarat yang ditetapkan oleh Menteri masih sangat terbatas dan belum bisa diakses dengan mudah di setiap wilayah Indonesia. Oleh karena itu, problematika pelaksanaan aborsi legal dan aman bagi korban perkosaan yang ditemukan dalam Undang-Undang Kesehatan ini harus segera diperbaiki, agar korban perkosaan tidak kembali menjadi korban akibat pelaksanaan praktek aborsi illegal yang tidak aman.

Kata Kunci: Problematika; Aborsi; Korban Perkosaan.

PENDAHULUAN

Perkosaan adalah salah satu kejahatan yang menakutkan bagi perempuan. Karena dampak dari perkosaan tidak hanya dirasakan ketika kejahatan tersebut dilakukan, tetapi juga berimbas pada masa yang akan datang. Virginitas perempuan yang terenggut paksa dalam kasus perkosaan, tidak akan pernah bisa dipulihkan lagi seumur hidupnya. Apalagi jika akibat perkosaan tersebut menimbulkan kehamilan yang pada dasarnya tidak dikehendaki oleh korban. Bahkan kehamilan itu adalah hasil dari kejahatan (Ekotama, dkk, 2001: 12). Perkosaan merupakan bentuk kekerasan seksual yang melanggar HAM dan merendahkan martabat perempuan. Deklarasi PBB untuk Penghapusan Kekerasan terhadap Perempuan Tahun 1993 mendefinisikan perkosaan sebagai perbuatan berdasarkan pembedaan berbasis gender yang berakibat kesengsaraan atau penderitaan perempuan secara fisik, seksual atau psikologis, termasuk ancaman terjadinya perbuatan tersebut, pemaksaan atau perampasan secara sewenang-wenang, baik yang terjadi di ruang publik maupun di dalam kehidupan pribadi (Rohmawati, 2015).

Perkosaan menjadi salah satu tolak ukur pelanggaran HAM yang cukup parah terhadap perempuan. Apa yang diperbuat pelaku merupakan bukti kesewenangwenangan dan kekejian yang bertentangan dengan watak diri manusia yang seharusnya menghormati dan melindungi hak-hak sesamanya (Kristiani, 2014). Korban perkosaan memiliki kemungkinan mengalami stres paska perkosaan yang dapat dibedakan menjadi dua, yaitu stres yang langsung terjadi dan stres jangka panjang. Stres yang langsung terjadi merupakan reaksi paska perkosaan seperti kesakitan secara fisik, rasa bersalah, takut, cemas, malu, marah, dan tidak berdaya. Stres jangka panjang merupakan gejala psikologis tertentu yang dirasakan korban sebagai suatu trauma yang menyebabkan korban memiliki rasa kurang percaya diri, konsep diri yang negatif, menutup diri dari pergaulan, dan juga reaksi somatik seperti jantung berdebar dan keringat berlebihan. Apabila setelah terjadinya 
peristiwa perkosaan tersebut tidak ada dukungan yang diberikan kepada korban, maka korban dapat mengalami post traumatic stress disorder (PTSD), yaitu gangguan secara emosi yang berupa mimpi buruk, sulit tidur, kehilangan nafsu makan, depresi, ketakutan dan stress akibat peristiwa yang dialami korban dan telah terjadi selama lebih dari 30 hari. Dukungan dari semua pihak sangat diperlukan untuk mencegah terjadinya PTSD (Ekandari, dkk, 2001).

Di Indonesia, kasus perkosaan sudah sangat sering terjadi, bahkan tercatat ada beberapa kasus perkosaan yang mendapat sorotan tajam dunia internasional. Kasus pertama, operasi militer yang diterapkan di Aceh sejak tahun 1989 sampai dengan awal Agustus 1998. Dampak buruk dari operasi tersebut selain mengakibatkan sejumlah orang tewas dan hilang akibat kekerasan, operasi tersebut juga telah menyebabkan 102 perempuan Aceh menjadi korban perkosaan (Ekotama, 115). Kasus Kedua, perkosaan massal yang menghebohkan dunia internasional terjadi pada tanggal 13-15 Mei 1998 di Jakarta. Dari hasil investigasi yang dilakukan Tim Relawan Untuk Kemanusiaan pimpinan I. Sandiawan Sumardi, SJ. (Romo Sandiawan) diperoleh fakta: korban perkosaan murni 103 orang (1 mati), perkosaan dan penganiayaan 26 orang (9 mati), perkosaan dan pembakaran 9 orang (semua mati), pelecehan seksual 14 orang (1 mati). Jadi, jumlah total korban 152 orang dengan 20 orang diantaranya mati. Semua korban adalah wanita keturunan
Tionghoa (Ibid:116). Kedua kasus perkosaan tersebut tidak pernah tuntas diselesaikan hingga saat ini.

Kasus perkosaan tidak berhenti sampai disitu, pada 24 Agustus 2013 lalu seorang siswi sekolah menengah kejuruan (SMK) berinisial NFR (16) diperkosa secara bergantian oleh tiga siswa hingga menyebabkan korban mengandung. Korban tidak dapat melawan karena tangannya diikat dan mulutnya disumpal. Mereka memerkosa korban di sebuah indekos di Cipinang Besar Selatan, Jatinegara, Jakarta Timur. Selanjutnya, pada Juni 2019 kemarin seorang gadis 16 tahun diperkosa oleh 5 orang temanya di Pinrang, Sulawesi Selatan hingga hamil. Semua kasus tersebut hanya sebagian kecil yang mengemuka ke publik. Hal ini terjadi karena anak-anak dan wanita adalah laten victims yang cenderung menjadi korban atas perlakuan orang lain yang punya kekuatan fisik maupun psikis yang lebih besar (Sahetapy, 1987: 117).

Tindak pidana perkosaan erat sekali kaitannya dengan fungsi reproduksi perempuan dan dapat menimbulkan kehamilan yang tidak diinginkan. Menjalani kehamilan itu berat, apalagi kehamilan yang tidak dikehendaki. Jika korban perkosaan mengalami kehamilan, korban pada umumnya akan berusaha menghentikan kehamilan tersebut, dengan melakukan berbagai upaya yakni dengan jalan aborsi, baik secara medis maupun non medis (Sari: 2013). Bagi korban perkosaan, pilihan untuk melanjutkan kehamilan atau melakukan tindakan aborsi adalah pilihan yang sama sulitnya. 
Yenny Fitri.Z : Problematika Pelaksanaan Aborsi Bagi Korban Perkosaan...

Pada dasarnya aborsi jelas merupakan tindakan yang dilarang, baik secara hukum, moral, etika, kesusilaan, dan agama (Panjimas, 2003). Meski dilarang, kasus aborsi di Indonesia justru menunjukkan peningkatan setiap tahunnya. Di Indonesia pada tahun 2015 saja angka aborsi sudah mencapai tiga juta kasus per tahun. Angka yang tidak sedikit mengingat besarnya tingkat kehamilan di Indonesia (Utami, dkk, 2015). Hal ini dapat terjadi karena hukum terlalu kaku dalam menerapkan aturan, tanpa memperhatikan kemungkinan dibenarkannya tindakan aborsi tersebut.

Sebagai jawaban atas permasalahan aborsi bagi korban perkosaan, pemerintah sudah melahirkan Undang-Undang Nomor 36 Tahun 2009 tentang Kesehatan yang selanjutnya diteruskan dengan melahirkan Peraturan Pemerintah Nomor 61 Tahun 2014 tentang Kesehatan Reproduksi yang menjadi payung hukum pelaksanaan aborsi aman bagi korban perkosaan. Namun, sejak payung hukum tersebut dilahirkan, sangat minim dan bahkan hampir tidak ada korban perkosaan yang menggunakan praktek aborsi aman ini sebagai jalan untuk menggugurkan kandungan yang tidak diinginkannya. Hal ini terjadi karena permasalahan di lapangan praktek, tidak semudah uraian teori yang dituangkan di dalam peraturan perundang-undangan. Sementara hampir setiap hari korban perkosaan terus berjatuhan di semua wilayah di Indonesia. Untuk menjawab persoalan tersebut, penulis tertarik untuk meneliti tentang Problematika
Pelaksanaan Aborsi Bagi Korban Perkosaan dalam Undang-Undang Nomor 36 Tahun 2009 tentang Kesehatan.

\section{METODE PENELITIAN}

Jenis penelitian yang digunakan dalam penulisan ini adalah jenis penelitian yuridis normatif. Penelitian normatif merupakan penelitian hukum yang dilakukan dengan cara meneliti bahan pustaka yang ada (Soekanto, dkk, 2009: 13). Pada penelitian hukum jenis ini, hukum seringkali dikonsepkan sebagai apa yang tertulis dalam peraturan perundang-undangan (law in book) atau hukum dikonsepkan sebagai kaidah atau norma yang merupakan patokan berprilaku manusia yang dianggap pantas (Amiruddin,dkk, tth: 118). Dengan penggunaan metode normatif diharapkan dapat menemukan persoalan atau problematika pelaksanaan aborsi bagi korban perkosaan berdasarkan UndangUndang Nomor 36 Tahun 2009 tentang Kesehatan.

\section{HASIL DAN PEMBAHASAN}

\section{Problematika Aborsi bagi Korban Perkosaan Berdasarkan KUHP}

Dalam KUHP, aborsi diatur pada BAB XIV tentang Kejahatan Terhadap Kesusilaan Pasal 299 dan BAB XIX tentang Kejahatan Terhadap Nyawa, yaitu Pasal 346 KUHP sampai dengan Pasal 349 KUHP. Namun KUHP tidak menggunakan istilah aborsi, melainkan memakai istilah menggugurkan atau mematikan kandungan Kata pengguguran kandungan adalah terjemahan dari kata abortus provocatus yang dalam kamus 
kedokteran diterjemahkan dengan “membuat keguguran". (Merpaung, 1999 :46).

Menurut ketentuan Pasal 346, 347, dan 348 KUHP, abortus provocatus criminalis meliputi perbuatan-perbuatan sebagai berikut :

a. Menggugurkan kandungan (afdrijving van de vrucht atau vruchtafdrijving).

b. Membunuh kandungan (de dood van de vruchtvoroorzaken atau vruchtdoden).

KUHP tidak memberikan penjelasan mengenai perbedaan pengertian menggugurkan kandungan atau membunuh kandungan, demikian pula mengenai pengertian kandungan atau arti dari istilah dari kandungan itu sendiri. Dari segi tata bahasa menggugurkan berarti membuat gugur atau menyebabkan gugur. Gugur sama artinya dengan jatuh atau lepas. Jadi menggugurkan kandungan berarti membuat kandungan menjadi gugur atau menyebabkan menjadi gugur (Tarore, 2013).

Pengaturan aborsi dalam KUHP mutlak dilarang tanpa ada pengecualian dan pelakunya dapat diancam pidana penjara. Namun, larangan di dalam KUHP tersebut ada alasan peniadaan pidananya, yaitu karena adanya daya paksa. Daya paksa ini sendiri terdiri atas 2, yaitu :

a. Daya yang memaksa secara fisik, sehingga orang yang dipaksa tidak dapat mengelak untuk melakukan perbuatan melawan hukum (vis absoluta) b. Daya yang memaksa secara psikis. Artinya meskipun secara pisik seseorang masih dapat menghindarinya, namun karena daya itu sedemikian besarnya maka dapat dimengerti seseorang tidak akan kuat menahan daya tersebut (vis compulsa) (Sarmida, dkk, 2003 : 136).

Kemudian, Moeljatno juga membagi daya paksa menjadi dua, yaitu daya paksa dalam arti sempit (overmacht) dan daya paksa keadaan darurat (noodtoestand). Daya paksa keadaan darurat (noodtoestand) terdiri atas 3 kemungkinan, yaitu :

a. Orang bertentangan dengan dua kepentingan;

b. Orang bertentangan dengan kepentingan dan kewajiban;

c. Orang bertentangan dengan dua kewajiban (Moeljatno, 1985:140)

Dalam kasus aborsi yang dilakukan oleh korban perkosaan, terjadi konflik antara dua kepentingan yaitu kepentingan korban perkosaan dan kepentingan anak yang dikandungnya. Selain itu juga terjadi konflik antara kepentingan dan kewajiban. Di satu sisi aborsi merupakan kepentingan korban perkosaan, namun di sisi lain ia juga dibebankan kewajiban untuk memelihara dan melahirkan anak yang dikandungnya. Oleh karenanya korban perkosaan seringkali melakukan aborsi atau pengguguran janin illegal secara sengaja. (Afifah, 2013).

Pilihan korban perkosaan untuk melakukan aborsi illegal, justru 
Yenny Fitri.Z : Problematika Pelaksanaan Aborsi Bagi Korban Perkosaan...

menimbulkan masalah baru karena berdampak pada sakit, komplikasi, pendarahan dan berujung pada kematian ibu. KUHP tidak hanya mempidana pelaku aborsi, namun juga para penolong tindakan aborsi tersebut termasuk di dalamnya dokter, perawat, dan bidan (Wijayati, 2015). Dalam KUHP dinilai terjadi ketidak adilan, karena pelaku aborsi akibat korban perkosaan dijatuhi hukuman yang sama dengan pelaku pemerkosaan (Sagita, dkk, 2018)

\section{Problematika Aborsi bagi Korban Perkosaan Berdasarkan Undang- Undang Nomor 36 Tahun 2009 tentang Kesehatan.}

Seperti yang telah diuraikan sebelumnya, perkosaan massal yang terjadi pada tanggal 13-15 Mei 1998 di Jakarta telah menyebabkan jumlah total korban 152 orang dengan 20 orang diantaranya tewas. Kasus perkosaan massal tersebut kemudian mendorong dilakukannya aborsi massal yang dilakukan oleh korban perkosaan pada periode reformasi di Jakarta (April-Mei 1998).Tujuan dilakukan aborsi ini pada awalnya sebagai upaya menolong para korban perkosaan tersebut untuk kembali pada kehidupan sosialnya sebelum peristiwa itu terjadi. Namun usulan dan tindakan yang dilakukan para relawan untuk kemanusiaan tersebut mendapat tanggapan pro dan kontra dari berbagai kalangan di tanah air. Hingga pada Diskusi Panel "Aborsi Dalam Kasus Perkosaan" yang dilakukan oleh Forum Kesehatan Perempuan di Jakarta 13 Agustus 1998 mengeluarkan pernyataan terbuka agar pemerintah melegalkan abortus provocatus bagi korban perkosaan. Pada saat itu usulan tersebut terdengar sangat radikal dan mustahil untuk diwujudkan mengingat negara Indonesia memiliki mayoritas penduduk beragama Islam. Perdebatan terjadi dan kajian dari berbagai ilmu pun bermunculan. Barulah pada tahun 2009 tepatnya melalui Undang-Undang Nomor 36 Tahun 2009 tentang Kesehatan yang menggantikan Undang-Undang Nomor 23 Tahun 1992, usulan tentang legalisasi terhadap abortus provocatus karena perkosaan tersebut berhasil diwujudkan (Budhiartie: 2011).

Undang-Undang Nomor 36 Tahun 2009 tentang Kesehatan ini dilahirkan untuk menjawab persoalan aborsi karena kehamilan akibat perkosaan yang tidak mampu di jawab oleh aturan KUHP maupun Undang-Undang Kesehatan sebelumnya Nomor 23 Tahun 1992. Sebelum dilakukan revisi terhadap undang-undang kesehatan, masih banyak perdebatan mengenai aborsi yang dilakukan oleh korban perkosaan termasuk tenaga medis yang membantu melakukan aborsi tersebut. Hal itu dikarenakan tidak terdapat pasal yang secara jelas mengatur mengenai aborsi terhadap korban perkosaan. Selama ini banyak pandangan yang menafsirkan bahwa aborsi terhadap korban perkosaan disamakan dengan indikasi medis, sehingga dapat dilakukan karena gangguan psikis terhadap ibu juga dapat mengancam nyawa sang ibu. Namun di pihak lain ada juga yang memandang 
bahwa aborsi terhadap korban perkosaan adalah aborsi kriminalis karena memang tidak membahayakan nyawa sang ibu (Susanti: 2012). Maka, dengan lahirnya Undang-Undang Nomor 36 Tahun 2009 tentang Kesehatan ini, menciptakan kepastian tentang legalisasi aborsi bagi korban perkosaan.

Pasal 75 Ayat (1) Undang-Undang Nomor 36 Tahun 2009 tentang Kesehatan dengan tegas melarang tindakan aborsi dengan menyatakan bahwa setiap orang dilarang melakukan aborsi. Namun terdapat 2 pengecualian untuk aturan tersebut seperti yang diatur dalam Pasal 75 Ayat (2) Undang-Undang Kesehatan, yaitu berdasarkan :

a. Indikasi kedaruratan medis yang dideteksi sejak usia dini kehamilan, baik yang mengancam nyawa ibu dan/atau janin, yang menderita penyakit genetik berat dan/atau cacat bawaan, maupun yang tidak dapat diperbaiki sehingga menyulitkan bayi tersebut hidup di luar kandungan; atau

b. Kehamilan akibat perkosaan yang dapat menyebabkan trauma psikologis bagi korban perkosaan.

Namun, tindakan aborsi tersebut hanya dapat dilakukan setelah melalui konseling dan/atau penasehatan pra tindakan dan diakhiri dengan konseling pasca tindakan yang dilakukan oleh konselor yang kompeten dan berwenang. Selain itu, Pasal 76 Undang-Undang Kesehatan ini juga mengatur bahwa tindakan aborsi hanya dapat dilakukan: a. Sebelum kehamilan berumur 6 (enam) minggu dihitung dari hari pertama haid terakhir, kecuali dalam hal kedaruratan medis;

b. Oleh tenaga kesehatan yang memiliki keterampilan dan kewenangan yang memiliki sertifikat yang ditetapkan oleh menteri;

c. Dengan persetujuan ibu hamil yang bersangkutan;

d. Dengan izin suami, kecuali korban perkosaan;

e. Penyedia layanan kesehatan yang memenuhi syarat yang ditetapkan oleh menteri.

Aturan Pasal 76 Undang-Undang Kesehatan ini kemudian diperjelas dalam Peraturan Pemerintah Nomor 61 Tahun 2014 tentang Kesehatan Reproduksi. Adapun dalam Pasal 31 sampai dengan Pasal 39 Peraturan Pemerintah Nomor 61 Tahun 2014 tentang Kesehatan Reproduksi menjelaskan tentang indikasi kedaruratan medis dan perkosaan sebagai pengecualian atas larangan aborsi atau dengan kata lain memperbolehkan aborsi berdasarkan indikasi kedaruratan medis atau akibat dari korban pemerkosaan. Untuk tindakan aborsi akibat dari korban pemerkosaan, batas usia kehamilan haruslah tidak lebih dari 40 hari dihitung sejak hari pertama haid terakhir. Selanjutnya, berdasarkan Pasal 34 Ayat (2) Peraturan Pemerintah Nomor 61 Tahun 2014 diketahui bahwa kehamilan akibat perkosaan harus dibuktikan dengan:

a. Usia kehamilan sesuai dengan kejadian perkosaan, yang dinyatakan oleh surat keterangan dokter; dan 
Yenny Fitri.Z : Problematika Pelaksanaan Aborsi Bagi Korban Perkosaan...

b. Keterangan penyidik, psikolog, dan/atau ahli lain mengenai adanya dugaan perkosaan.

Jika dilihat ketentuan Pasal 76 Undang-Undang Kesehatan ini, syarat untuk mengakses layanan aborsi ini sangat rumit dan berat. Ini menjadi salah satu masalah yang membuat korban perkosaan lebih memilih layanan aborsi illegal dibandingkan yang legal dan aman. Beberapa kesulitan tersebut adalah :

a. Tindakan aborsi hanya dapat dilakukan sebelum kehamilan berumur 6 (enam) minggu dihitung dari hari pertama haid terakhir, kecuali dalam hal kedaruratan medis. Kenyataannya, bagi korban perkosaan, ada perasan tertekan, takut dan malu bagi mereka untuk menyampaikan kasus perkosaan yang mereka alami kepada orang lain. Selain itu, bagi mereka korban perkosaan yang masih usia sangat muda, pengetahuan seputar reproduksinya masih sangat minim. Sehingga mengakibatkan mereka tidak bisa menghitung secara akurat siklus haid dan tanda-tanda terjadinya kehamilan. Dengan demikian, waktu 6 minggu bagi wanita yang hamil akibat menjadi korban perkosaan dinilai terlalu cepat dan singkat.

Masa kehamilan berumur 6 (enam) minggu dihitung dari hari pertama haid terakhir ini artinya sekitar 40 hari sesuai dengan aturan Pasal 31 sampai dengan Pasal 39 Peraturan Pemerintah Nomor 61 Tahun 2014 tentang Kesehatan Reproduksi. Hal ini sejalan juga dengan Fatwa Majelis Ulama Indonesia (MUI) Nomor 4 Tahun 2005 Tentang Aborsi yang dikeluarkan pada tanggal 21 Mei 2005. Dalam fatwa tersebut disebutkan bahwa aborsi yang dilakukan oleh perempuan korban perkosaan dibolehkan asal dilakukan sebelum janin berusia 40 hari. Hal ini mengacu kepada Hadits Rasulullah SAW yang berbunyi :

"setiap kamu dikumpulkan dalam rahim ibumu selama empat puluh hari, kemudian berubah menjadi sesuatu yang melekat juga dalam waktu empat puluh hari, kemudian berubah menjadi gumpalan daging juga dalam masa empat puluh hari. Setelah itu Allah mengutus Malaikat untuk melengkapi empat hal, yaitu rezki, ajal, sengsara dan bahagia. Barulah setelah itu ditiupkan ruh kedalamnya (H.R. al-Buhkari dari ibn Mas'ud) (Saifullah, tth : 121)

Berkaitan dengan hadits diatas, para ulama berbeda pendapat mengenai aborsi yang dilakukan sebelum janin diberi nyawa. Perbedaan ini disebabkan karena perbedaan dalam memahami Hadits Rasullullah tersebut. Ada ulama yang berpendapat ruh ditiupkan setelah lampau waktu 40 hari, ada yang berpendapat 80 hari, dan ada juga yang berpendapat ruh ditiupkan setelah lampau masa 120 hari usia kandungan.

Terlepas dari perbedaan pendapat itu, jika mengacu kepada aturan yang sudah dilegalkan di Jerman, aborsi 
hanya dapat dilakukan untuk kasus perkosaan atau jika kehamilan tersebut mengancam jiwa sang ibu, dan usia kandungannya belum mencapai 3 bulan (Ummat, 1995). Aturan sejenis bisa dijadikan rujukan bagi kehamilan akibat perkosaan, dimana usia kandungan untuk dilakukannya aborsi ditingkatkan menjadi 3 bulan mengingat pertimbangan-pertimbangan mental dan psikologis korban perkosaan yang telah diuraikan sebelumnya. Apalagi diketahui bahwa tindakan aborsi adalah operasi yang sangat aman. Bahkan teknik aborsi sampai usia kehamilan 15 minggu (3-4 bulan usia kehamilan) lebih aman dari pada operasi amandel (Ariyanto : 2014). Jika demikian halnya, maka batas usia kandungan yang ditetapkan maksimal 40 hari untuk dapat dilakukannya aborsi bagi korban perkosaan dinilai terlalu singkat dan tergesa-gesa. Aborsi menjadi salah satu masalah yang cukup serius dan perlu penanganan segera, dan dalam lapangan ilmu kedokteran pun telah cukup meresahkan, sehingga lahirlah pemahaman bahwa aborsi merupakan desakan berbagai pihak agar masalah kapan dimulainya sebuah kehidupan dan pula kehidupan itu dianggap tidak ada, dapat diagendakan secepatnya (Mulyana : 2017).

b. Aborsi hanya dapat dilakukan oleh tenaga kesehatan yang memiliki keterampilan dan kewenangan serta memiliki sertifikat yang ditetapkan oleh menteri. Penyelenggaraan pelayanan aborsi ini sudah diatur secara rinci dalam Peraturan Menteri Kesehatan (Permenkes) Nomor 3 Tahun 2016 tentang Pelatihan dan Penyelenggaraan Pelayanan Aborsi. Dalam peraturan itu disebutkan, pelayanan aborsi atas indikasi kedaruratan medis dan kehamilan akibat perkosaan harus dilakukan dengan aman, bermutu, dan bertanggung jawab yang dilakukan oleh dokter sesuai dengan standar profesi, standar pelayanan, dan standar prosedur operasional. Namun, hingga saat ini negara belum mengimplementasikan layanan aborsi legal dan aman bagi kehamilan akibat perkosaan, sebagaimana yang telah diamanatkan oleh peraturan perundang-undangan. Hal ini terjadi karena Kementerian Kesehatan belum pernah mempersiapkan persyaratan pelatihan terhadap tenaga medis, juga pelatihan konseling untuk aborsi bagi korban perkosaan yang mengalami Kehamilan yang Tidak Diinginkan (KTD). Sehingga sampai saat ini, korban perkosaan yang mengalami KTD belum bisa mendapatkan pelayanan aborsi aman, karena belum adanya tenaga medis, serta tempat layanan resmi yang disediakan oleh Kementerian kesehatan. Hal ini lantas membuat layanan aborsi yang aman di fasilitas umum tetap sulit diakses. Dampaknya yang paling utama adalah meningkatnya kebutuhan layanan aborsi ilegal dan tidak aman.

c. Tindakan aborsi hanya dapat dilakukan pada penyedia layanan 
Yenny Fitri.Z : Problematika Pelaksanaan Aborsi Bagi Korban Perkosaan...

kesehatan yang memenuhi syarat yang ditetapkan oleh Menteri. Kenyataannya, hingga saat ini sangat minim sekali tersedia Rumah Sakit, Klinik atau penyedia layanan kesehatan lainnya yang memenuhi syarat untuk melakukan tindakan aborsi yang aman bagi korban perkosaan. Sementara Indonesia adalah negara kepulauan yang sangat luas dan bisa dipastikan akan terjadi kasus perkosaan disetiap wilayahnya. Jika pemerintah hanya mampu menyediakan layanan kesehatan aborsi yang memenuhi syarat di beberapa kota besar di Indonesia, tentu akan semakin menyulitkan bagi wanita korban perkosaan ini untuk memenuhi hak nya melakukan aborsi yang legal dan aman pada penyedia layanan kesehatan yang sudah ditentukan. Padahal, Konferensi Internasional Kependudukan dan Pembangunan (ICPD) di Kairo Tahun 1994 dan Konferensi Wanita di Beijing tahun 1995 telah menyepakati bahwa akses pada pelayanan aborsi yang aman merupakan bagian dari hak wanita untuk hidup, hak wanita untuk menerima standar pelayanan kesehatan dan informasi (Munawaroh: 2015).

Berdasarkan persoalan-persoalan dan kesulitan untuk mengakses layanan aborsi bagi korban perkosaan seperti yang telah diuraikan diatas, terlihat bahwa legalitas aborsi bagi korban perkosaan masih dilakukan setengah hati, sehingga pilihannya bagi korban perkosaan terpaksa kembali kepada layanan aborsi illegal. Menurut Bharoto Winardi, ada beberapa kemungkinan buruk yang akan dihadapi seorang perempuan hamil jika melakukan aborsi diluar prosedur medis, diantaranya :

a. Pendarahan dengan segala akibatnya. Hal ini terjadi karena pengguguran dilakukan dengan cara dan dengan peralatan yang tidak semestinya digunakan untuk menggugurkan kandungan.

b. Infeksi. Peralatan aborsi yang tidak diperhatikan suci hamanya dapat mengakibatkan infeksi tetanus. Infeksi ini pun dapat berakibat jangka panjang maupun jangka pendek bagi wanita hamil.

c. Dampak psikologis pasien. Perempuan yang melakukan aborsi illegal dan non procedural biasanya merasa bersalah seumur hidup (guilty feeling). Efek jangka panjang dari perasaan bersalah ini dapat berpengaruh pada kelangsungan proses produksi berikutnya.

d. Emboli, yaitu adanya benda yang masuk kedalam sirkulasi darah sehingga menyumbat pembuluh darah dan mengakibatkan matinya wanita hamil yang bersangkutan.

e. Tindakan lanjutan. Setelah melakukan aborsi, tidak semua wanita bisa sembuh dengan sendirinya. Ada yang memerlukan perawatan lanjutan atau berobat jalan. (Ekotama: 54)

Oleh karena itu, pemerintah sudah seharusnya mengatasi secepatnya berbagai problematika dalam pelaksanaan 
aborsi legal dan aman bagi korban perkosaan. Agar korban perkosaan tidak kembali menjadi korban akibat pelaksanaan praktek aborsi illegal yang tidak aman.

\section{SIMPULAN}

Berdasarkan uraian yang telah dipaparkan pada bagian sebelumnya, maka dapat ditarik kesimpulan sebagai berikut :

1. Di dalam KUHP, tindakan aborsi mutlak dilarang tanpa adanya pengecualian. Kekakuan pengaturan di dalam KUHP ini menimbulkan banyak permasalahan dan dilema.

2. Undang-Undang Nomor 36 Tahun 2009 tentang Kesehatan yang kemudian dilanjutkan dengan Peraturan Pemerintah Nomor 61 Tahun 2014 dan Peraturan Menteri Kesehatan Nomor 3 Tahun 2016 tentang Pelatihan dan Penyelenggaraan Pelayanan Aborsi menjadi legalitas tindakan aborsi bagi korban perkosaan untuk menjawab kekakuan KUHP. Namun dalam pelaksanaannya, ditemukan tiga persoalan yang membuat korban perkosaan kesulitan memperoleh haknya untuk mendapatkan pelayanan aborsi yang aman dan legal. Persoalan tersebut meliputi usia kandungan yang ditetapkan maksimal 40 hari untuk dapat dilakukannya aborsi bagi korban perkosaan dinilai terlalu singkat, Kementerian Kesehatan belum pernah mempersiapkan persyaratan pelatihan terhadap tenaga medis, juga pelatihan konseling untuk aborsi bagi korban perkosaan, serta layanan kesehatan yang memenuhi syarat yang ditetapkan oleh Menteri masih sangat terbatas dan belum bisa diakses dengan mudah di setiap daerah.

\section{UCAPAN TERIMAKASIH}

Puji dan syukur Penulis ucapkan atas Rahmad dan Kemudahan yang Allah SWT berikan dalam penyelesaian jurnal yang berjudul Problematika Pelaksanaan Aborsi bagi Korban Perkosaan dalam Undang-Undang Nomor 36 Tahun 2009 Tentang Kesehatan. Banyak pihak yang telah ikut berkontribusi di dalam penyelesaian jurnal ini, yaitu :

1. Bapak Dr. Eviandi Ibrahim S.H,.M.Hum selaku Ketua Sekolah Tinggi Ilmu Hukum Putri Maharaja Payakumbuh.

2. Seluruh rekan dosen dan karyawan di Sekolah Tinggi Ilmu Hukum Putri Maharaja yang tidak dapat disebutkan satu persatu.

\section{DAFTAR PUSTAKA}

\section{Buku-buku}

Suryono Ekotama, dkk, 2001, Abortus Provocatus bagi Korban Perkosaan Perspektif Viktimologi, Kriminologi, dan Hukum Pidana, Universitas Atma Jaya, Yogyakarta.

J.E. Sahetapy (editor), 1987, Viktimologi Sebuah Bunga Rampai, Pustaka Sinar Harapan, Jakarta.

Soerjono Soekanto dan Sri Mamudji, 2009, Penelitian Hukum Normatif Suatu Tinjauan Singkat, Cet.11, PT Raja Grafindo Persada, Jakarta.

Amiruddin dan Zainal Asikin, tth, Pengantar Metode Penelitian Hukum, PT. Raja Grafindo Persada, Jakarta.

Leden Merpaung, 1999, Tindak Pidana Terhadap Nyawa dan Tubuh, Sinar Grafika, Jakarta. 
Yenny Fitri.Z : Problematika Pelaksanaan Aborsi Bagi Korban Perkosaan...

Neng Sarmida, dkk, 2003, Diktat Hukum

Pidana, Universitas Andalas,

Padang.

Moeljatno, 1985, Asas-Asas Hukum Pidana, Bina Aksara, Jakarta.

Saifullah, Tth, Abortus dan Permasalahannya (Suatu Kajian Hukum Islam) dalam Problematika Hukum Islam Kontemporer II.

\section{Jurnal}

Rohmawati, 2015, Tinjauan Hukum Islam Terhadap Legalitas Aborsi Akibat Perkosaan dalam PP No. 61 Tahun 2014, AHKAM, Vol. 3/ No. 1, Hal. 65-94.

Ni Made Dwi Kristiani, 2014, Kejahatan Kekerasan Seksual (Perkosaan) Ditinjau Dari Perspektif Kriminologi, Jurnal Magister Hukum Udayana, Vol. 7/ No. 3, Hal. 371-382.

Ekandari,dkk, 2001, Perkosaan, Dampak, Dan ALternatif Penyembuhannya, Jurnal Psikologi , Nomor 1, Hal. 118.

Riza Yuniar Sari, 2013, Aborsi Korban Perkosaan Perspektif Hukum Islam dan Hak Asasi Manusia, ALHUKAMA The Indonesian Journal of Islamic Family Law, Vol. 03/ No. 01, Hal.34-81.

Panjimas, 2003, Lika-Liku Melegalkan Aborsi, Hal.22.

Tanti Kirana Utami \& Aji Mulyana, 2015, Tanggung Jawab Dokter Dalam Melakukan Aborsi Tanpa Seizin Ibu Yang Mengandung Atau Keluarga Dalam Perspektif Hukum Positif Di Indonesia, Jurnal Mimbar Justitia, Vol. I/ No. 02, Hal. 499-517.
Freedom Bramky Johnatan Tarore, 2013, Pengguguran Kandungan Akibat Pemerkosaan Dalam KUHP, Lex Crimen, Vol. II/No. 2, Hal. 32-33.

Wiwik Afifah, 2013, Perlindungan Hukum Bagi Perempuan Korban Perkosaan Yang Melakukan Aborsi, DiH: Jurnal Ilmu Hukum, Vol 9/No 18, Hal. 93-109.

Mufliha Wijayati, 2015, Aborsi Akibat Kehamilan Yang Tak Diinginkan, ANALISIS: Jurnal Studi Keislaman, Vol. 15/ No.1, Hal.4362.

Fahma Sagita, Chepi Ali Firman Z, 2018, Perlindungan Hukum Korban Perkosaan Berdasarkan Undang Undang Kesehatan Nomor 36 Tahun 2009 Jo Peraturan Menteri Nomor 3 Tahun 2016 tentang Pelatihan dan Penyelenggaraan Pelayanan Aborsi Atas Indikasi Kedaruratan Medis dan Kehamilan Akibat Perkosaan,Prosiding Ilmu Hukum, Vol. 4/ No. 2, Hal.712-717.

Arrie Budhiartie, 2011, Legalisasi Abortus Provocatus Karena Perkosaan Sebagai Implementasi Hak Asasi Perempuan (Analisis Yuridis Pasal 75 Undang-Undang Nomor 36 Tahun 2009 Tentang Kesehatan), ISSN 0852-8349, Vol. 13/ No. 2, Hal. 59-72.

Yuli Susanti, 2012, Perlindungan Hukum Bagi Pelaku Tindak Pidana Aborsi (Abortus Provocatus) Korban Perkosaan, FH.UNISBA, Vol. XIV/ No. 2, Hal-290-311.

Ariyanto, 2014, Abortus Provocatus Bagi Korban Pemerkosaan Ditinjau dari Perspektif Penegakan Hukum 
Pidana di Wilayah Kota Jayapura, Legal Pluralism, Vol.4/No.1, Hal. 77-101.

Aji Mulyana, 2017, Perlindungan Hukum Terhadap Perempuan dan Anak Akibat Tindak Pidana Abortus Provocatus Criminalis, Wawasan Yuridika, Vol.1/ No. 2, Hal. 139154.

Munawaroh, 2015, Aborsi Akibat Pemerkosaan dan Kedaruratan Medis Menurut Hukum Islam, Mizan; Jurnal Ilmu Syariah, FAI Universitas Ibn Khaldun (UIKA), Vol. 3/ No. 2,Hal 295-350

\section{Peraturan Perundang-Undangan}

Kitab Undang-Undang Hukum Pidana.

Undang-Undang Nomor 36 Tahun 2009 tentang Kesehatan.

Peraturan Pemerintah Nomor 61 Tahun 2014 tentang Kesehatan Reproduksi.
Peraturan Menteri Kesehatan Nomor 3 Tahun 2016 tentang Pelatihan dan Penyelenggaraan Pelayanan Aborsi.

Fatwa Majelis Ulama Indonesia (MUI) Nomor 4 Tahun 2005 Tentang Aborsi.

\section{WEBSITE}

https://jambi.tribunnews.com/2013/12/13/ siswi-jadi-hamil-usai-diperkosabergantian-penempat-indekosminta-jatah, akses 22 Agustus 2019 Pukul 21.30 Wib.

Hasrul Nawir, https://news.detik.com/berita/d4597688/gadis-di-pinrang-yangdiperkosa-5-orang-hamil-danmasih-trauma, akses 22 Agustus 2019 Pukul 21.45 Wib. 